\title{
Pedagogical Strategies of Visual Art in Colleges of Education
}

\author{
SUMAILA ISSAH $^{{ }^{1 *}}$ AHETO-DOMI BRAIN ${ }^{2}$ EBENEZER K. ACQUAH, PHD ${ }^{3}$ \\ 1.Bia Lamplighter College of Education, Sefwi Debiso Department of Creative Arts, P. O. Box 97, Sefwi - \\ Debiso, Ghana \\ 2.Peki College of Education, Department of Technical and Vocational Education, P. O. Box 14, Peki - Volta \\ Region Ghana \\ 3.University of Education, Winneba Department of Graphic Design, P. O. Box 25, Winneba - Ghana
}

\begin{abstract}
This paper examines the implementation of the visual art curriculum at Wiawso College of Education (WATICO) in Ghana. The discussion touches on the pedagogical strategies and methods used in the teaching of the visual art programme at the WATICO and also to examine it implications on the trained teacher expected to teach Visual Art aspect of Basic Design and Technology (BDT) at the Basic Education level. Purposive sampling technique was used. Three main methods viz. interview, personal observations, and documentary review were employed. Teacher performance evaluation and Inductive analysis strategy were used as reference materials for the analysis. The study revealed that the art teachers at WATICO demonstrated high level of competency of knowledge in the subject matter. However, the teaching and learning of art component BDT at WATICO was more theoretical than practical and in spite of the tutors' mastery in the preparation of lesson notes, the research revealed that the visual art at WATICO does not equip the teacher-trainee with teaching and learning skills in all the three areas of BDT (Visual Arts, Home Economics, and Technical Skills). The findings of the study cannot be generalized for colleges of education in Ghana since it was limited to only WATICO in the Western Region of Ghana. It was concluded that, the pedagogical strategies and methods adopted for the teaching and learning of visual art at WATICO were diverse, yet appropriate for the visual art. However, teaching and learning of visual art at the basic level were observed to be more theoretical than practical demonstration and application. It is recommended that the use of learner centred approach to teaching coupled with diverse teaching methods as practiced in WATICO should be consolidated.
\end{abstract}

Keywords: pedagogy, art, education and implementation

DOI: $10.7176 / \mathrm{ADS} / 77-01$

Publication date:October $31^{\text {st }} 2019$

\subsection{Introduction}

The foundation of every growing society depends on the fundamental knowledge and culture transmitted to its pupils. In Ghana, the formal basic education process starts from the classroom. Based on good instructional directions given by a teacher, an infant's learning domain system (involving three taxonomies) is well-prepared for societal goals and national development as a whole. As such, in an effort to speed up national development, there is the need to set a strong base through the nurturing of good instructors. Grisham-Brown, Pretti-Frontczak, Hawkins, and Winchell (2009) observe that good teaching requires expert decision making. This calls for solid professional preparation that requires sound professional development and regular opportunities to work collaboratively with other teachers. According to Giudici, Rinaldi and Krechevsky (2001, p.8) "based on careful and sensitive listening, observation/documentation, and reflection with other adults, the teachers serve as resources and guides to the children". They also found those teachers that have acquired skill in visual art guide students to work with different media symbol systems. Teachers organise environments rich in possibilities and challenges that invite the children to undertake extended exploration and problem solving, often in smaller groups (cohorts), where cooperation and disputation mingle pleasurably. However, what to teach, where, when, why and how it should be done are based on national educational policies and in a country such as Ghana, both educational and cultural polices define the curricula, especially in public schools.

It is envisaged that a well-grounded visual arts education would encourage personal development and create awareness of both the cultural heritage and the role of art in society. The major purposes of visual arts education are derived from the personal, social and historical functions of general education. This assertion is amply emphasised by Laura Chapman, a renowned art educator (as cited in Sun, 2004), that, three major purposes of art education stem from the personal, social and historical responsibilities of general education. Visual art education helps a teacher to transmit good society norms and behaviours to the learners. Chapman also found in modern communication and advertising that, art works are used to develop critical and inquisitive mind in the individual. Furthermore, a person's ability to use the cognitive, affective, and psychomotor domains effectively can be nurtured through visual art education. These involve active exploration of ideas, materials, tools, equipment and processes. It enables a person to acquire knowledge, apply, synthesis, analysis and evaluates issues when there is visual thinking in creative activity. Again, visual art education provides a child with a vocation for life. Visual 
art education provides people with the opportunity to acquire hands-on experience to solve problems that confront them and the entire society. A sound mind in a sound body, as emphasized by Greek philosophy, is attained through practical activities in art and that equips the learner with requisite skills to solve problems that confront him/her in the immediate environment.

The essence of arts education cannot be downplayed. For instance, arts subjects such as visual art, music, dance and drama help individuals to form their own opinion and apply aesthetic ideas to his/her own situation. In Ghana, the cultural policy promulgated in 2004 advocates for significant opportunities for students to experience the Visual arts and use them to create expressions that make life worth living. It also emphasized on equipping our pre-service teachers with the required knowledge in and about the arts to be able to deliver the expected goods in our schools' (NCC, 2004). Therefore, the visual art educator needs to acquire relevant training that will prepare him/her adequately to teach students. However, a cursory observation of the visual art component in the colleges of education curriculum in Ghana reveals traces of inadequacies. Meanwhile, most of the teachers teaching at the basic school level are the graduates from the colleges of education.

In order to unravel and understand the true nature of the current situation concerning the pedagogical strategy and teaching method employed in teaching visual art at the colleges of education in Ghana, the researcher focused on WATICO in the Western Region of Ghana.

\subsection{Research Questions}

The study was guided by the following research questions:

- How is the Visual Art programme structured at Wiawso College of Education?

- What teaching style and method exhibited by Tutors handling Visual Art programme Wiawso College of Education?

- What are the causation of the adapted strategies and methods used by Tutors on Past Students from WATICO teaching at the basic level?

The purpose of the study was to evaluate the pedagogical strategies and methods used in the teaching of the visual art programme at the Wiawso College of Education in Ghana and to examine it application past students teaching BDT at the basic level.

\subsection{Literature Review}

This section reviews literature on the basics of teaching Art in schools in Ghana

Successful methods and competencies in teaching and learning hinge on motivational skills and persona, instructional strategies and assessment skills as well as communication skills (Duku, 2012). Methods used in teaching are categorized into two main cords, viz. teacher-centred and learner-centred.

The teacher centred method of teaching comprises inviting experts as speakers to deliver a talk, directed discussions, cohort (focus group) discussion, direct teaching, corporate training, expert's panel, lecture as well as lecture discussion (Duku, 2012). The teacher centred method starts with existing body of knowledge that an individual student possess independently of the teacher. In the body of knowledge, the teacher is highly viewed as the primary expert. Teaching is therefore assumed to exist when knowledge is transmitted to the student from the teacher.

According to Nilson (2010), learner centred includes activities such as brainstorming, fieldworks, peer feedback from students, case method, inquiry guided learning, recitation, group learning, clinical, and problem based learning as well as role plays. The concepts of learner centred methods are teaching practices and instructional designs that are primarily based on the recognition of the learner. Ghanaian institutions have been encouraged to use learner centred approach in teaching and learning due to the fact that students satisfaction and learning outcomes are increasingly becoming paramount (Duku, 2012). The learner centred is seen as effective method of ensuring teaching and learning in an effective instructional design environment. According to Petty (2009), learning is seen as a hidden mental process for which the teacher has no direct control over. In the learner centred approach of teaching, the student is considered as the main aim underpinning teaching and learning. Learner centred approach of teaching borders on concepts that specifically address the needs and characteristics of particular group of students.

The methodology of teaching based on learner centred approach represents educational and instructional philosophy that has reshaped, reformed and redefined the traditional approach of teacher centred educational formats for the key ingredient of teaching and learning (Petty, 2009). In Ghana, the discussion of teaching and learning methods based on either teacher centred or learner centred have primarily focused on primary and secondary education with tertiary institution gradually joining the discussion (Barber, 2007). The teacher centred approach is defined as the format in which the teacher is seen as the only source of knowledge and the communication of knowledge to the students is primarily the responsibility of the teacher (Duku, 2012). Since the teachers have an expertise in the subjects they teach, they decide the content and structure. According to Attard, Di Ioron, Geven and Santa (2010), the teacher centred approach is based on the model of active teacher 
and passive students whereas the learner centred approach is based on the principle of active student and passive teacher.

In Ghana, schools at the various levels have been encouraged to use learner centred approach as an alternate to teacher centred approach in the teaching and learning of Art Education due to the fact that learner centred has superior strength than teacher centred (Nilson, 2010). In the teaching and learning of art education, feedbacks are necessary to facilitate improvement of learning outcomes. Duku (2012) examined feedback from students on the course content stated objectives by lecturers and what was actually taught by the lecturers in his Pedagogic Foundation of Art Education in Ghana. Duku reveals that, 85\% of students interviewed stated that, lecturers of Art Education thoroughly explained the objectives of the course content to them and about $64 \%$ of respondents also stated that, lecturers actually taught what were stated.

In Ghana, Art education encourages and ensures that students are inquisitive and ask question during teaching and learning of the course (Duku, 2012). Art education sees lecturers as facilitators or guides rather than being the sole source of knowledge. This presupposes that art education employs the learner centred pedagogy approach rather than teacher centred pedagogical approach. The practice of art education in encouraging student centred approach supports 21 st century teaching and learning where the focused has shifted from the teacher being the transmitter of knowledge to the student to the teacher being the supporter and guilder of students to learn in a regulated learning environment (Van Eekelen et al., 2005).

There are several methods, approaches and techniques in the teaching of art education in Ghanaian schools. However, the techniques employed in the teaching and learning of art education depends on the content of the course, resources and situation under which the teaching is being done. In art education, teaching that is based on practice is preferred to any method, approach or technique that encourages memorization subject facts (Van Eekelen et al., 2005; Duku, 2012).

In art education, curriculum is designed to encourage independent learning of the student thereby resulting in creativity (Lambert \& McCombs, 2000). This means that, students are free to express themselves and display their innate creativity leading to effective contribution to the study. Art is regarded as a symbol of language which uses signs and symbols. Imperatively, lecturers are therefore advised to use teaching aids to help the student understanding in the teaching and learning of art education. According to Duku (2010), the training of teachers for art education must not only ensure that the teacher employs effective teaching and learning aids but the trainees must also be given the opportunity to use and have access to the teaching aid where appropriate. Irrespective of the fact that, art education curriculum is designed for the purpose of training teachers for schools nationwide; it also provides practical skills (Duku, 2012).

\subsection{Methodology}

Qualitative approach was employed to enable the researcher seek and explore the views of key persons and informants concerning the problem under investigation. In the light of this, the case study research design offers a much more appropriate approach. The use of the case study design also allows the researcher to investigate how well the teaching and learning of arts has been in the selected college of education using interview and other survey methods.

The population of this study therefore included all principals, tutors, administrators, students and past students of Colleges of Education in Ghana. Since it will be difficult to involve all people within the population in the study, the researcher selected a sample of 38 respondents. The sample included 4 students, 6 immediate past students (teachers), 22 pupils learning BDT, the Principal, a senior Administrative Officer, and 4 Tutors of the WATICO. Even though no statistical technique was employed in the determination of the sample size, the size was selected to meet the criteria of objectivity and to minimise sampling error and systematic bias. The selection of the sample also took into consideration the need to be able to collect in-depth information through interviews.

A non-random sampling method was used in the selecting of respondents for the study. In the first place, the selection of the WATICO was done purposively. WATICO is part of the 46 colleges of education in the country that runs art education programmes. Therefore, WATICO was seen as an institution that can serve as information hub and source of knowledge on the problems of Art education in the country.

Three main data collection tools were employed in the collection of data for the study. These include interview (and also student experience survey and focus group discussion) personal observations and documentary review. The interview guides, observational sheets and focus group discussion guides were used to guide the observation and questioning of key informants (Principal, Tutors and Administrator) and classroom interactions. The use of interview in the study was necessary to probing are asked to ensure clarity of information provided. With the interview guide no specific questions were stated but left opened for the interviewer to be able to probe and obtain rich and in-depth information.

With the observational sheet too, critical areas were listed and considered as the focus area of the observation. The sheet was divided into thematic areas based on the objectives of the study and used to help the 
researcher/observer focus on key areas in the course of the observation. The content of the sheet was however to allow for researcher to take note of important observation necessary for the study.

The analysis, interpretation, and discussion of the findings were done using an inductive analysis strategy and teacher performance evaluation from the Handbook for Teachers on Performance Management Professional Requirements Manual published by the National Teachers Council and Ghana Education Service (2017). The analysis process, therefore, started with the identification of themes and patterns derived from similarities, differences, and sequences in responses. This occurred immediately after the data collection. In the process of the analyses, the researcher was guided by the research questions, the overall design of the research and the nature of the data collected. The data were therefore analyzed with the thoughtful balance between generating themes from within the data and applying preconceived themes to data generated.

\subsection{Results and Discussion}

\subsection{Demographic Characteristics of Respondents}

The respondents of the study included tutors in the Vocational and Technical Skill Department at WATICO, current students and past students of the Visual Arts Programme of the WATICO who are teaching, pupils in schools with WATICO trained teachers teaching the (visual arts component) Basic Design Technology subject.

In total, 38 respondents were contacted and participated in the study which included tutors at WATICO, past students of WATICO who were teachers at the selected basic schools, Principal and Administrator at WATICO and past students of WATICO teaching the art related subjects as well as students of WATICO and pupils of basic schools being taught by past students of WATICO. A combination of evaluation and assessment criteria relevant for the respondents were employed in obtaining the empirical data for the study.

In all four (4) of the Tutors at WATICO of which three (3) are males and one female were part of the study. The past students contacted too were six (6) in numbers (4 males and 2 females) and these were teachers of BDT at the Presbyterian Junior High School (JHS), Naana Biney JHS, Sefwi Dwamenase JHS, Sefwi Asafo Pentecost JHS and WATICO Demonstration JHS all located in Sefwi Wiawso. Tutors and Teachers of the Basic Design and Technology (BDT) course remain the most appropriate authorities when it comes to challenges faced in the teaching and learning of art related subjects in schools.

Four (4) current students of the WATICO of which one was a male and three (3) females were also contacted in the study. The current students of WATICO are trainees in the Basic Design and Technology (BDT) course expected to teach at the basic level of the Ghanaian education system. The students were involved in the process of empirical data collection through Students Experience Survey (SES) using an interview guide. This was necessary as to ascertain the veracity of challenges, pedagogical skills, teaching and learning methods being implemented in WATICO. Also, twenty two (22) pupils were in groups for focus group discussions. These students were randomly selected from schools that had teachers who were WATICO past students teaching the art related course. The schools were purposively selected and they comprised Presbyterian JHS, Sewfi Dwamenase JHS, Naana Biney JHS, Sefwi Asafo Pentecost JHS and WATICO Demonstration JHS.

One Administrator and the Principal of WATICO were also interviewed. The demographic characteristics of the respondents are presented in Table 1.

Table 1: Demographic Characteristics of the Respondents

\section{Category of \\ Respondents}

Tutor/ Teachers

Students/Pupils

Administrators

(Principal and an Administrator)

Total

\section{School}

WATICO

Presbyterian JHS

Naana Biney JHS

Sefwi Dwamenase JHS

WATICO Demonstration JHS

Sefwi Asafo Pentecost JHS

WATICO

Presbyterian JHS

Naana Biney JHS

Sefwi Dwamenase JHS

WATICO Demonstration JHS

Sefwi Asafo Pentecost JHS

WATICO

$\begin{array}{lll}\begin{array}{l}\text { Number of Participants } \\ \text { Males }\end{array} & \begin{array}{l}\text { Females } \\ \text { Tota }\end{array} & \\ 3 & 1 & 4 \\ 1 & 1 & 2 \\ 0 & 1 & 1 \\ 1 & 0 & 1 \\ 1 & 0 & 1 \\ 1 & 0 & 1 \\ 1 & 3 & 4 \\ 2 & 2 & 4 \\ 2 & 2 & 4 \\ 2 & 3 & 5 \\ 2 & 2 & 4 \\ 2 & 3 & 5 \\ 2 & 0 & 2\end{array}$

Source: Field survey, 2017 


\subsection{Pedagogical Strategies and Methods used in the Teaching of the Art at WATICO}

The teaching and learning of art education take different forms and methods. One of the key objectives of the study was to assess the pedagogical strategies and methods employed in the teaching of art programme at the Wiawso College of Education. The study took into consideration the structure and the composition of art programme as clearly stipulated in the course hand-out of students as well as the approved course contents by the colleges of education; Pedagogical strategies and teaching style being employed by tutors of Wiawso College of Education in the teaching and learning of art programme; and finally the application of pedagogical strategies and teaching styles by past students of WATICO in the teaching and learning of art programme at the basic level of education.

\subsection{How is the Visual Art programme structured at Wiawso College of Education?}

At Wiawso College of Education, the Vocational and Technical Skills Programme is under the Department of Vocational and Technical (VOC/TEC). The department runs the course Technical and vocational skills. Technical skills are studied by students offering Mathematics and Technical, and Science and Technical while Vocational skills are studied by students offering the social science programme.

Vocational skills are an umbrella name given to Home Economics and Visual Arts taught and learned in the Colleges of Education in Ghana in recent times. It is a core and elective subject studied by teacher trainees with the exception of those studying Science and Mathematics and Technical, Science and Technical, and French Programmes in some Colleges of Education in Ghana. At WATICO, students in level 100 offering social science program study fundamentals in visual art as core in first year first semester. As an optional elective by level 200 students known as Principles and Methods of Teaching Visual Arts in first semester and Visual Communication in second semester. The Home Economics include catering and sewing whereas the Visual Arts have been classified as two-dimensional and three-dimensional art forms. Two-dimensional arts are any form of Artefact or Artwork that is designed or created to have length and breadth and usually on a flat surface. Examples of such Art forms are Drawings, Paintings, Posters, Collage, Mosaic, Greeting Cards, Banners, Billboards, Buntings, Pennants, and many others. They are normally designed or executed on surfaces of many kinds. Threedimensional arts are however the type of art works created or designed to have length, breadth, and height and mostly classified with form. For this reason, it is real to observe that the Three-Dimensional Art forms have volume. They are as well designed and created in solid materials such as wood, clay, stone, sawdust, cane, straw, raffia, bamboo, plastics, plasticine, ivory, bone, marble, Plaster of Paris (POP), fibre, seeds, glass, cement etc. example of which include: pots, tea cups and jugs, carved drums, linguist staffs, stools, baskets, bags, hats, wallets, belts, statues, busts, bracelets, anklets, bracelets and many others. The course description prepared by the Institute of Education, University of Cape Coast describes the Visual Art related subjects as: "This course provides the fundamentals for the study of Vocational Skills-Visual Arts in the Diploma Programme. It covers fundamental concepts common to all Visual Arts subjects to provide a broad-based education of the generalist teacher trainee". (Ministry of Education, 2006 p.4).

Based on the course description as provided by the approved body for teacher education, it can, therefore, be deduced that the teaching and learning of art related subjects is to demonstrate an understanding of the nature and scope of Visual Arts knowledge in basic concepts and practical skills in fundamentals in Visual Arts. The Hand-Out prepared by Tutors of visual art subject at Wiawso College of Education and approved by the College Board which is based on the Course outline and content provided by Institute of Education, University of Cape Coast provides the rationale for the teaching and learning of Visual Art as:

The rationale aimed at establishing the following requirements:

- Fostering Creativity

- Holistic Education

- Acquisition of skills

- Self-Reliance

- $\quad$ Leisure and Recreational Activities / Past times

- Preservation and Appreciation of our Cultural Heritage

- Personal Development

- $\quad$ Exploration and use of tools and materials

By fostering creativity the subject trains the individual to think critically in order to produce new things. This can only occur when individual's original ideas are manifested in physical forms. In the student experience survey, students (thus teacher trainees) were asked to state their opinion on the relevance of the visual art course curriculum in WATICO. The responses are presented as follows:

- A very useful programme if taught in the lower and upper primary effectively. This is because it develops the creativity in children (Teacher Trainee, Wiawso College of Education, Level 200).

- It helps students to be creative in the world of arts (Teacher Trainee, Wiawso College of Education, Level 100) 
With respect to art providing the students with holistic education, each unique single individual has three Domains which need to be developed, trained or nurtured. These are the Cognitive Domain (Brain), Psychomotor domain (Muscles) and the Affective domain which concerns the (Heart). This expectation is corroborated by the teacher trainees as the rationale sinks well with them.

Art is a diverse course which in its diabolic ways helps the individual to develop in all domains of life being cognitive, affective and psychomotor. It also helps to discover hidden potentials and talents in individuals. (Teacher Trainee, Wiawso College of Education, Level 200)

Students are trained to do things and do them very well. Skill is the ability to do something well based on enough training and experience. They are taught the processes involved in the production of a variety of art works. For example, students are taught about proportion, balance, tempering of tools, in sculpture. The student is offered the opportunity to identify, prepare and use a variety of tools and materials in making or creating artefacts. During these activities, the student learns how to prepare tools, how to use the tools, how to maintain and store these tools and materials after work in order to extend their lifespan. As part of the student's experience survey (SES), the trainee teachers indicated that the study of art related subjects enables them to be creative and acquires creative skills and knowledge.

Not only does art education helps students to acquire basic knowledge and skills but it also helps students discover their abilities, potentials, and talents as the study results shows. From the focus group discussion, they emphasised that it creates awareness for them to discover their hidden potentials, abilities, and talents. It also informs them to know about the relevance of art in order to clear all unfounded misconceptions.

The scope of the Visual Arts in the Diploma programme at the Colleges of Education covers the primary or basic skills required by trainees to equip them to teach the subject at the basic education level with ease and efficiency. The basic skills expected to be acquired by student teachers in Visual Arts Related Subjects are drawing, cutting, planning and organizing, appreciating, shading, measuring, perceiving, composition, critical observation, printing, weaving, carving, modelling, casting, embossing, skiving, tanning, glazing, priming, sketching, reeding, scouring among many other skills. The results of the study demonstrate that the art programme is composed of theory and practical. This composition and structure are evident in the course content and outline of visual art subjects and courses at WATICO as well as responses from Tutors of WATICO, Past Students and Now Teachers and current students of WATICO. The students experience survey conducted also revealed that the art programme in Wiawso College of Education contains both aspects of theory and practical lessons and sometimes the tutor demonstrated what they were supposed to do, as specified by past students.

This account from past students of Wiawso College of Education was confirmed by both current students of the college and tutors at WATICO. The practicality of visual art education at WATICO is very consistent to the development and idea behind the teaching and learning of art. Art education is beneficial to the students in so many ways. The teaching and learning of visual art as evident in the study results allows students to communicate with ease. This assertion was adequately confirmed by a current student at WATICO during the data collection. She stated that Visual Arts is fun and allows students to communicate with the general public and others with the arrangements of signs, symbols, pictures, illustrations, and others to express thoughts and feelings.

Though the structure of art programme is composed of both theory and practicals, the study results indicate, the teaching and learning of art related subjects at Wiawso College of Education were practically oriented than theoretical concepts. The results confirm a study conducted by Van Eekelen et al., (2005) which stated that, in art education, teaching that is based on practice is preferred to any method, approach or technique that encourages memorization of subject facts. The findings are also in consonance with an assertion made by Lambert and McCombs (2000) that in art education, the curriculum is designed to encourage independent learning of the student thereby resulting in creativity. This presupposes that students are at liberty to freely express themselves and display their innate creativity leading to an effective contribution to the study. The experience of students at Wiawso College of Education with respect to how a typical lesson in art subjects is consistent with an assertion by Duku (2010), which indicated that, Art is regarded as a symbol of language which uses signs and symbols.

Interestingly, there seems to be a great disparity and disconnect between the visual art programme structure prepared by the Institute of Education, University of Cape Coast, for colleges of education and the structure of Basic Design and Technology (BDT) designed by the Ghana Education Service for the teaching of art at the basic level. In the interview session with past students of WATICO, a substantial number of them raised the differences and the disparities between the course content at the various levels of education. For instance, two teachers (past students of WATICO) stated that, what they learned at the College of Education was quite different from the syllabus they were using to teach the BDT subject. They suggested that the teaching and learning of Art in college need to be integrative (combining Home Economics, Technical Skills, and Visual Arts). They further argued for it to be made compulsory, if possible, and the college can also add BDT as a subject that would combine all three aspects. 
The development of course content and outline for the teaching and learning of art education must bear some sort of resemblance and similarity. In that, at the Colleges of Education, though the art programme is designed to encourage creativity, innovation and skills development, it is essential to ensure that what the teacher will be teaching at the basic level is adequately integrated. The results of the study show otherwise, indicating that teachers are not well-informed and prepared in the BDT subject structure at the basic levels since it deviates significantly from the college level.

\subsection{What teaching style and method are exhibited by Tutors handling Visual Art programme Wiawso College of Education?}

Teaching methods and styles are relevant for students' understanding and knowledge gaining in visual art education. It must be stated that the teaching of art subjects cannot be treated as the teaching of mathematics, biology, sociology, history as well many other courses. Often times, the styles and methods in which teachers use in the classroom go a long way to have an impact on students' academic performance and understanding. Art education requires teaching styles and methods that would encourage active students' participation and involvement, by which the teacher is expected to play the role of a facilitator. The teaching methods and style employed in the visual art education programme at the colleges of education are based on the pedagogical foundation underpinning the study of the art programme. In this study, an approach to teaching and learning of art at WATICO was studied to understand the pedagogical strategies and style used in teaching art programme in the college.

The results show that, methods used in teaching art at the Wiawso College of Education include lectures, demonstrations, group works, brainstorming, field works, and problem based learning as specified in the Handbook for Teachers on Performance Management - Professional Requirements Manual published by the National Teachers Council and Ghana Education Service (2017). For the purpose of the study, the pedagogical strategies employed in teaching and learning is categorized into two: teacher centered approach and learner centered approach. The method and the style of teaching demonstrate which of the teaching style is employed. Whereas the teacher centered approach sees the teacher as the active participant while the student centered approach see the student as the active participant and the teacher as the facilitator.

The results from the finding indicate that the teaching style and methods at the WATICO are more of students centered than the teacher centered. This shows that students are considered the most active participants in the classroom when it comes to the teaching and learning of visual art at Wiawso College of Education (WATICO).

The findings of the study in relation to the teaching methods and style at the Wiawso College of Education support the assertion made by Nilson (2010) which states that, learner-centered includes activities such as brainstorming, fieldworks, peer feedback from students, case method, inquiry-guided learning, recitation in Arts, group learning, clinical, and problem-based learning as well as role plays. The approaches used in teaching art program at the WATICO are appropriate as far as the teaching of courses is concerned in Ghana. WATICO Tutors of art programmes base their teaching on the student centered approach. In that instance, the teacher sees the student as the active participant and there is, therefore, a general interaction in the classroom among students and teachers. The pedagogical strategies of teaching art at WATICO is consistent with recommendation of previous studies which encourages the use of student centered approach at all level of education in Ghana (Duku, 2012). In Ghana, schools at the various levels have been encouraged to use the learner centered approach as an alternative to teacher-centered approach in the teaching and learning of Art Education due to the fact that learner-centered has superior strength than teacher centered (Nilson, 2010). This statement is supported by the fact that, feedback from students which are necessary and paramount in the teaching of art subjects are found in the student's centered approach.

As indicated by the results in Table 2, the features of the lecture being used in the teaching of visual art programme at WATICO consist of prepared lesson plan based on the course content and outline approved for teaching at the Colleges of Education. It also contains notes and materials obtained by tutors for the preparation of lessons plans. The lecture takes into account the presentation of the theoretical concepts of the art subject and its application in practical terms to students. As observed at WATICO, the lectures take place in a classroom setting where the participation of students is highly encouraged as typical of students centered pedagogical skills.

In terms of demonstration methods as observed and indicated in Table 2, Tutors demonstrate practically to students what are taught during the lesson delivery processes. They demonstrate theory delivered through the lecture to students using available Teaching and Learning Materials (TLMs). Teaching and Learning Materials used by Tutors include colours, design materials, materials for drawing, and others. The practical application of art programme is relevant to ensure that teachers' potential and skills are well developed to enable them to perform at the basic level of education. As such, the demonstration during lessons by Tutors of visual art programme at WATICO is in tandem with the overall objective of the teaching and learning of programme at all levels of education in Ghana. 
Group works and assignments in an educational setting are normally encouraged to promote teamwork among students. It also encourages students to learn and understand the course well, as it is believed that students are able to learn and understand well when taught by their peers (Dylan, 2013). As the results show in Table 2, students are put into groups to practically demonstrate what the Tutor taught through the lecture and the demonstration methods. Some Tutors also give groups assignments and homework for students to engage in teamwork. The group works help in the teaching and effective participation of students in the classroom environment and setting.

Brainstorming as part of art teaching and learning is integrated at the Colleges of Education conforming to the pedagogical skills of students centered approach. As demonstrated in Table 2, students are taken through some process of brainstorming during the teaching of art to enable them developed ideas based on the course taught. Idea development is also enhanced through practical demonstration of the concepts. Brainstorming in the teaching and learning of art programme promotes and enhances the thinking and creativity of students. This, therefore, prepares the students to adequately and effectively teach the visual art subjects at the basic level.

The results of the study also show that field works are a major component of the teaching style used in Wiawso College of Education. Here, field works basically consist of practical demonstration of what is taught in the classroom. In this instance, students are involved in actual practical works to produce their own artefacts as a means of demonstrating the knowledge acquired in the classroom. As indicated in Table 2, field work include projects works, field trips and a visit to an art gallery by students to have an artistic impression of what is taught in the classroom. Duku (2010) reiterates that, art education curriculum is designed for the purpose of training teachers for schools nationwide and also provides practical skills. The practical skills of the students can be demonstrated and enhanced through field works and activities that are designed to enhance the potential skills of the learner.

Problem Based Learning (PBL) has been integrated into many academic disciplines to challenge their thoughts and thinking abilities. Pedagogical strategy that is also well executed in teaching visual art programme at Wiawso College of Education is Problem Based Learning, as indicated in the results. Table 2 shows that, the features of PBL include the use of real life cases that are presented to students to solve problems using the concepts of art. In the PBL, students apply their knowledge in the art programme to solve problems facing society through art concepts. The pedagogical strategies and teaching style used in teaching teacher trainees at WATICO is expected to have an effect on the teaching and learning of Basic Design and Technology (BDT) at the basic level of Ghana Education Service (GES). The overall effect of the teaching methods at WATICO is expected to enhance the teaching and learning skills of trainees to adequately prepare them at the basic schools. As demonstrated by the study, the teaching methods used in teaching art programmes at WATICO to a large extent conform to the many suggestions and recommendations concerning how art is supposed to be taught in schools in Ghana (Duku, 2012; UNESCO, 2006).

\section{Table 2: Methods used in Teaching Art at the WATICO}

Teaching Methods

Features

Lecture

Tutors prepare lecture notes and lesson plan based on approved course content and outline; use of other relevant course materials and notes; lectures take place in classroom setting involving students' participation.

Demonstration Tutors practically demonstrate theory delivered through the lecture to students using Methods available Teaching and Learning Materials (TLMs). Teaching and Learning Materials used by Tutors include poster colours, design materials, materials for drawing, and others.

Group works Students are put into groups to practically demonstrate what the tutor taught through the lecture and the demonstration methods. Some tutors also give group assignments and home-works for students to engage in teamwork.

Brainstorming Students are taken through some process of brainstorming during the teaching of art to enable them develop ideas based on the course taught. Idea development is also enhanced through practical demonstration of the concepts.

Field Works This is the actual practical demonstration by students in all that they learned in the classroom. This consists of mini projects that students are allowed to do for assessment and grading by tutors.

Problem Based The features of PBL include the use of real life cases that are presented to students to Learning (PBL) solve using the concepts of art. In the PBL students. Students apply their knowledge in the art programme to solve problems facing society through art concepts.

Source: Field Survey, 2017

4.5 What are the causation of the adapted strategies and methods used by Tutors on Past Students from WATICO teaching at the basic level?

The application of pedagogical strategies and teaching methods learned at WATICO by past students are 
expected at the basic level. Pedagogical skills hinge on motivational skills and persona, instructional strategies and assessment skills as well as communication skills. Past students from WATICO are taught through a set of teaching styles and methods during their study at the college. In this study, an assessment was carried out through observation of Past students in some selected basic schools in Sefwi Wiawso to find out whether or not a student is able to apply the methods and styles in which they were taught at the college level.

The results of the study show a vast difference between the teaching methods and style at WATICO and one that was applied at the basic levels by past students of WATICO. Although the teaching methods and style adopted at WATICO ensures that the students play an active role in the teaching and learning process, the situation is different at the basic level where past students of WATICO teach. The techniques employed in the teaching and learning of visual art at the selected schools that had past students of WATICO relied on the content of the course, resources and situation under which the teaching was done. The sharp contradiction of the teaching and learning methods at the various levels indicates that past students of WATICO are not able to apply what they learnt at college.

Again, the results of the study as indicated in Table 3 show that, only two out of five teaching methods learned by past students are implemented at their basic schools of teaching. Whereas WATICO Tutors use pedagogical strategies and teaching styles such as lectures, demonstration methods, field works, brainstorming and group works, only two are applied by past students: these are lectures and demonstration methods. In some schools, only the lecture method of lesson delivery is applied without any practical lessons.

Table 3 shows that the teacher-centered approach was the main strategy applied at the basic level of education. The teacher is seen as a depository of knowledge and these limits students' activities in the teaching of art. This method is not appropriate for the art subject at the basic level since it does not encourage active involvement and participation of students thereby inhibiting the students' creativity and thinking potentials.

At the Presbyterian JHS, the teacher used two pedagogical strategies and teaching styles learned at WATICO. These were a lecture in the form of lesson delivery and demonstration methods. Though lessons were well taught in WATICO and, tutors demonstrated some artworks and also allowed students to do some basic designs, field works, brainstorming and group works which are active skills and strategies in art education were completely missing. Also at Methodist JHS and WATICO Demonstration JHS pupils study art subjects through the theoretical delivery of lessons and practical demonstration of art. The situation at Naana Biney JHS was worse. Since lessons were delivered without any practical demonstration, some basic concepts of the art subjects were not properly introduced to the students. One observation made at the basic schools where WATICO past students teach was that, though teachers had the opportunity to apply all pedagogical strategies and teaching styles learned at WATICO, the situations at the basic levels did not allow them to exhibit what they have learnt.

Table 3: Strategies and Teaching Methods used by Past Students

\begin{tabular}{|c|c|c|c|}
\hline Schools & Teaching Meth & hods & Observations \\
\hline Presbyterian JHS & $\begin{array}{l}\text { Lesson } \\
\text { (Lecture), } \\
\text { Demonstration } \\
\text { Methods }\end{array}$ & Delivery & $\begin{array}{l}\text { Very Good introduction of concepts. The students were asked to } \\
\text { do some basic designs and the tutor commented on some by } \\
\text { appreciating their efforts. Enough examples were given from the } \\
\text { environment but the lesson lacked TLMS }\end{array}$ \\
\hline Methodist JHS & $\begin{array}{l}\text { Lesson } \\
\text { (Lecture) }\end{array}$ & Delivery & $\begin{array}{l}\text { The teacher taught pupils without any practical demonstration of } \\
\text { artistic design. The class lacked course materials, art tools, and } \\
\text { basic design materials }\end{array}$ \\
\hline $\begin{array}{l}\text { Sefwi } \\
\text { Dwamenase JHS }\end{array}$ & $\begin{array}{l}\text { Lesson } \\
\text { (Lecture) }\end{array}$ & Delivery & $\begin{array}{l}\text { Lessons were taught with no practical demonstration, field work } \\
\text { or group works }\end{array}$ \\
\hline $\begin{array}{l}\text { WATICO } \\
\text { Demonstration } \\
\text { JHS }\end{array}$ & $\begin{array}{l}\text { Lesson } \\
\text { (Lecture), } \\
\text { Demonstration } \\
\text { Methods }\end{array}$ & Delivery & $\begin{array}{l}\text { Teacher taught students very well and demonstrated the } \\
\text { production of some art works to students }\end{array}$ \\
\hline Naana Biney JHS & $\begin{array}{l}\text { Lesson } \\
\text { (Lecture) }\end{array}$ & Delivery & $\begin{array}{l}\text { Lesson poorly delivered coupled with false concepts in some } \\
\text { areas. Lack of adequate knowledge of the subject matter. Lack of } \\
\text { proper method of presentation. Lesson presented orally devoid of } \\
\text { activities }\end{array}$ \\
\hline
\end{tabular}

Source: Field survey, 2017

\subsection{Conclusions}

From the analysis of the data based on research questions, it can be concluded that the pedagogical strategies and methods adopted for the teaching and learning of art programmes at Wiawso College of Education were diverse, yet appropriate for the art programme. However, teaching and learning of art programme at basic level where past student from WATICO teaches were observed to be more theoretical than practical demonstration and application. Further analysis revealed that the implication of teaching and learning methods on the past students 
of WATICO was largely dependent how they were taught and what they learned at WATICO. Whereas students who studied visual art at WATICO show good understanding and knowledge of the subject matter, the teaching and learning style and pedagogical skills differ from what they learned at WATICO.

Also, the visual art education programme at Wiawso College of Education does not equip the learner with teaching and learning skills in all the three areas of BDT. The analysis of the study data further revealed that the colleges of education face a lot of challenges such as inadequate of art studio, lack of teaching and learning materials and inadequate teaching aids, as well as course structure disparity between content of art programme at training colleges and that of BDT at the basic level. It can therefore be concluded that inadequate supply of teaching and learning materials at WATICO adversely impact on lesson delivery. These challenges affect art students and art programme thereby affecting the performance of art teachers both at WATICO and the basic level of education in Ghana.

\subsection{Recommendations}

The study recommends that the use of learner centred approach to teaching coupled with diverse teaching methods as practiced in WATICO should be consolidated. However, the practical component of BDT should be intensified and in-service training programmes should be organized quarterly for the tutors to be abreast with changing demands of teaching and learning of art education (discipline-based art education).

It is recommended that teachers at WATICO should devote valuable time to evaluate lessons and enable trainee teachers to do appraisal of their work. The Principals of the Colleges of Education as well as Heads of Basic Schools must make a conscious efforts and appeal to the Ministry of Education to set up a committee between the Institute of Education, UCC, Teacher Education Division and Curriculum Research and Development Division of Ghana Education service to ensure complete review of the course content and structure at the various level of education. This will help eliminate the disparity and variations that exist across art programme contents at the various level of education in Ghana.

\section{References}

Attard, A., Di Iorio, E., Geven, K., \& Santa, R. (2010). Student centred learning: An insight into theory and practice content. Retrieved on January 30, 2017, from http://www.esib.org/documents/publications/An_Insight_Into_Theory_And_Practice_T4SCL.pdf.

Barber, M. (2007). Reassessing pedagogy in a fast forward age. International Journal of Learning, 13, 143-149.

Duku F. K. (2012). Pedagogic foundation of art education in Ghana. Arts and Design Studies 4, 32-38.

Dylan, W. (2013). Assessment: The Bridge between Teaching and Learning. Voices from

the Middle, 21(2), 15-20.

Giudici, C., Rinaldi, C., \& Krechevsky, M. (2001). Making learning visible: Children as individual and group learners. Cambridge, MA: Project Zero, Harvard Graduate School of Education.

Grisham-Brown, J., Pretti-Frontczak, K., Hawkins, S. R., \& Winchell, B. N. (2009). Addressing early learning standards for all children within blended preschool classrooms. Topics in Early Childhood Special Education, 29(3), 131-142.

Lambert, N., \& McCombs, B. (2000). Introduction: Learner-centered schools and classrooms as a direction for school reform. In N. Lambert, \& B. McCombs (Eds.), How students learn (pp. 1-15). Washington, D.C.: American Psychological Association.

National Teachers Council \& Ghana Education Service (2017). Handbook for Teachers on Performance Management - Professional Requirements Manual. Retrieved on August 15, 2017 from https://www.gespostings.net/documents/PA\%20HAND\%20BOOK\%20\%20\%20FOR\%20TEACHERS.pdf

Ministry of Education. (2006). Pre-Vocational Skills Art Related Teaching Syllabus for Teacher Training Colleges. Revised Edition

Nilson, L. B. (2010). Teaching at its best: A research-based resource for college instructors. (3rd Ed.). San Francisco, CA: Jossey-Bass.

National Commission on Culture. (2004). The Cultural Policy of Ghana. Dedicated to the people of Ghana. Retrieved on December 12, 2015 from http://www.ghanaculture.gov.gh

Petty, G. (2009). Teaching today, a practical guide (4th Ed.). Cheltenham, UK: Nelson Thornes Ltd.

Sun (2004, February 8). Case for Making Art a Core Subject of the Teacher Education Reform Program. GhanaWeb. Retrieved on March12, 2016 from mobile.ghanaweb.com/.../Case-for-Makin...

Van Eekelen, I.M., Boshuizen, H.P.A and Vermunt, J.D (2005). Self-Regulation in Higher Education Teacher Learning. In Higher Education, 50, 447-471. 